\title{
Biogas Production from Different Agricultural Residues
}

\author{
Heba K. Hussien*, El-Sayed G. Khater**, Adel H. Bahnasawy*** and Ramy M. Hamouda**** \\ ${ }^{*}$ M.Sc. student of Agric. Eng. Dept., Fac. of Agric., Benha Univ. \\ ** Associate Professor of Agricultural Engineering, Faculty of Agriculture, Moshtohor, Benha University \\ *** Professor of Agricultural Engineering 'Faculty of Agriculture, Moshtohor, Benha University \\ **** Doctor of Agricultural Engineering, Agricultural Engineering Department, Benha University, Egypt
}

Corresponding author: hebakhalid17@yahoo.com

\begin{abstract}
The main aim of this work is to study the biogas production from different agricultural residues to overcome the energy scarcity and environmental pollution. To achieve that study the different types of mixing (Dairy manure (100:0), Poultry litter (100:0), Dairy manure, poultry litter and rice straw (25:25:50), Dairy manure and rice straw (20:80), Dairy manure and rice straw (80:20), Dairy manure, poultry litter and rice straw (40:40:20) and Poultry litter and rice straw (50:50)) on the total solids, volatile solids of slurry, biogas yield, methane yield, $\mathrm{CO}_{2}$ and $\mathrm{H}_{2} \mathrm{~S}$. The results show that the total solids (TS) and volatile solids (VS) of slurry decrease with increasing retention time for all treatments. The highest value of accumulated biogas yield ( $260.93 \mathrm{~m}^{3}$ per ton TS) was found with the Poultry litter and rice straw (50:50). Meanwhile, the lowest value of accumulated biogas yield $\left(229.96 \mathrm{~m}^{3}\right.$ per ton TS) was found with Dairy manure, poultry litter and rice straw (25:25:50). The highest value of accumulated methane yield $\left(196.10 \mathrm{~m}^{3}\right.$ per ton TS) was found with the Poultry litter and rice straw (50:50). Meanwhile, the lowest value of accumulated methane yield $\left(156.30 \mathrm{~m}^{3}\right.$ per ton TS) was found with Dairy manure $(100: 0) . \mathrm{CO}_{2}$ and $\mathrm{H}_{2} \mathrm{~S}$ increase with increasing retention time for all treatments.
\end{abstract}

Keywords: biogas yield, cattle manure, Total solids, Volatile solids, Methanne.

\section{Introduction}

Biogas is a product of anaerobic degradation of organic substrates, which is one of the oldest processes used for the treatment of industrial wastes and stabilization of sludges. Since it is carried out by a consortium of microorganisms and depends on various factors like $\mathrm{pH}$, temperature, $\mathrm{HRT}, \mathrm{C} / \mathrm{N}$ ratio, etc., it is a relatively slow process. Lack of process stability, low loading rates, slow recovery after failure and specific requirements for waste composition are some of the other limitations associated with it (Van der Berg and Kennedy, 1983).

Anaerobic digestion has been proven to be an efficient and green technology in disposing of sewage sludge, crop residues, food waste and animal manure (Wan et al., 2011 and Li et al., 2009). Advantages are the production of renewable energy in the form of biogas and the possibility to recycle valuable nutrients, concentrated in the digestion residue (Zhang et al., 2012 and Angelidaki et al., 2003).

Anaerobic digestion of organic waste and residues combines both sustainable treatment and renewable energy production. Some substrates, such as lignocellulosic materials, are resistant to anaerobic digestion and can be converted into biogas, although only to low extents. The low susceptibility of these materials to conversion into biogas is attributed to their composition and structure. Lignocellulose is the complex and rigid matrix of plant cells; it is resistant to enzymatic attack because of the tight association between lignin, cellulose, and hemicellulose. Cellulose and hemicellulose can be degraded in biogas processes. However, lignin cannot be degraded under anaerobic conditions (Fernandes et al., 2009).
Organic waste, being a source of pollution (water and soil pollution in storage sites, unpleasant odors, greenhouse gas emissions during decomposition, pathogenic bacteria, etc.), is not only an environmental issue but also an economic loss. Given the emphasis on the issue of depletion of fossil fuels, it is necessary to find solutions for the problems related to the availability of energy sources (Lakatos et al., 2016 and Meyer, 2017). Given these prospects, the conversion of organic waste into primary or secondary sources of raw materials used in energy technologies is the subject of many studies, which leads to the sustainable development of environment and society as well as the economy (Hayashi $\boldsymbol{e t}$ al., 2016 and Hausknost et al., 2017).

The rural biogas utilization of agricultural crops in china is regarded as typical waste treatment for energy utilization. In this field, many studies have been conducted on biomass waste. Not only for sole substrate but also co-digestions process have attracted much attention. Callaghana et al. (2002) studied the co-digestions of cattle slurry with fruit/vegetable waste and with chicken manure. Under mesophilic conditions, the retention time was kept at 21 days, and the organic loading rate (OLR) was maintained at 3.19 - $5.01 \mathrm{kgVS} / \mathrm{m}^{3}$.day. The possible use of potato tuber and its industrial by-products (potato stillage and potato peels) on farm scale co-digestion with pig manure was evaluated in a laboratory experiment (Kaparaju and Rintala, 2005).

Methane production from biomass waste has attracting more and more interest. While, the conventional digestion process directly accepting raw waste using continuous stirred tank reactor needs a long HRT and has a low VS removal rate. So, usually 
the digestion of biomass waste could not give satisfied results. Appels provide a detailed and comprehensive review of sludge anaerobic digestion. The researcher points out that hydrolysis is recognized as ratelimiting step in the complex anaerobic digestion process (Appels et al., 2008).

The convential energy become very expensive and harm environment. Due to the gradual increasing on convential energy prices in addition to the pollution. Agricultural wastes cause pollution and diseases and pests spading, therefore, the main aim of this work is to study the biogas production from different agricultural residues to overcome the energy scarcity and environmental pollution.

\section{Materials and methods:}

The experiment was carried out at Agricultural and Bio-Systems Engineering Department, Faculty of Agriculture Moshtohor, Benha University, Egypt. During the period of July to September, 2019 season to study the effect of fermentation temperature and agitation speed on biogas quality and productivity.

\section{Materials:}

\subsection{System description}

Figure (1) illustrates the system description. It shows the system which consists of digester tanks, heating tank, heat exchanger, mold and gas bag.

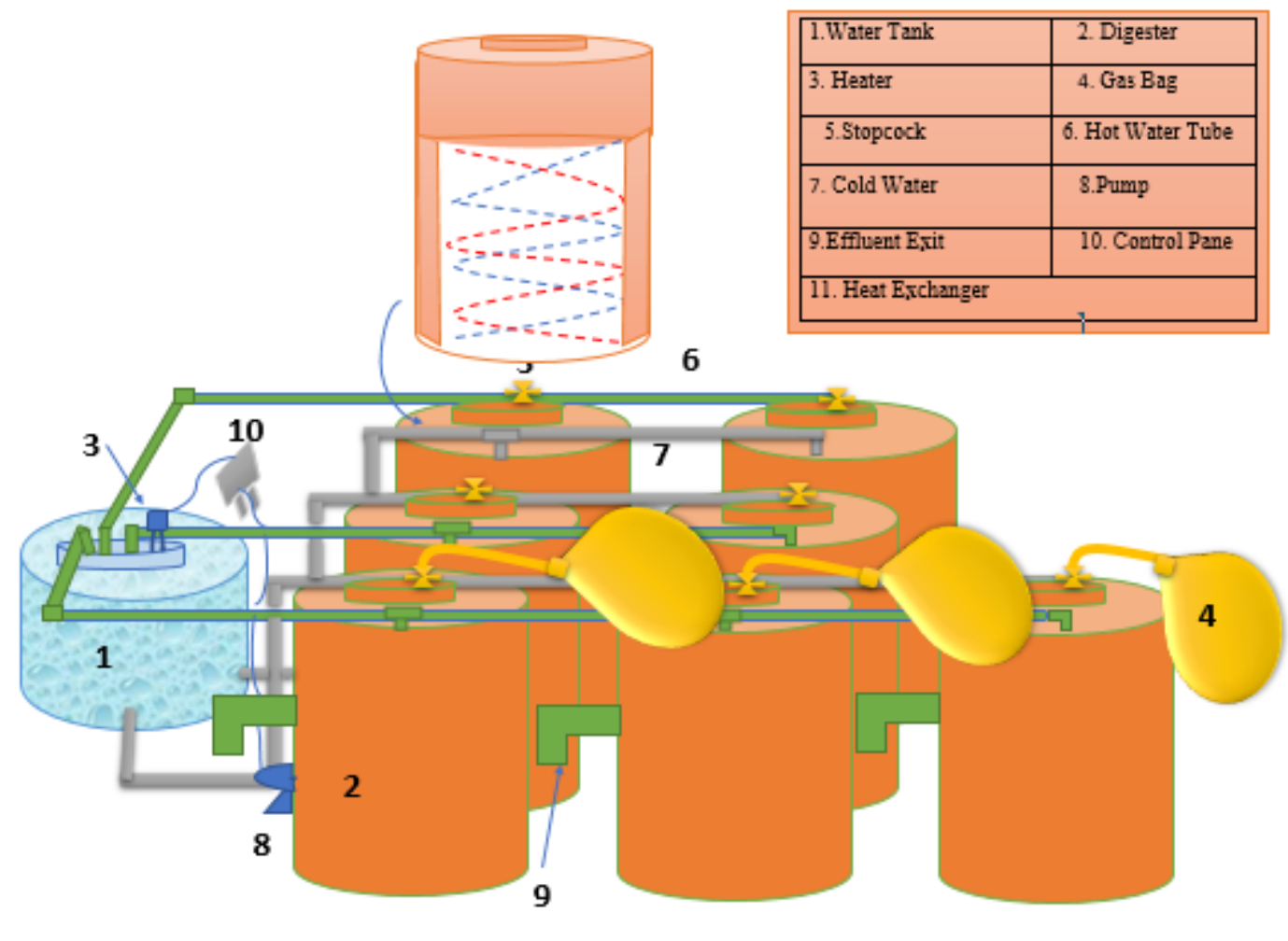

Figure (1): The experimental setup.

The system consists of seven digester tanks $1.0 \mathrm{~m}^{3}$ capacity that used for biogas production. Dimensions of each tank are $1.0 \mathrm{~m}$ diameter and $1.3 \mathrm{~m}$ height. It is made of polyethylene and covered by glass rock sheet. A four inch PVC pipe diameter was used for feeding the raw materials, the length of feeding pipe was 0.88 $\mathrm{m}$. Also, the digester tank was provided with drainage opening at high $1.0 \mathrm{~m}$ above the digester bottom. The diameter of drainage hole was three inches. The mixing system consisted of (a) a stainless steel mixing shaft (1 inch diameter and $1.0 \mathrm{~m}$ length) installed through the center of the tank, (b) six-vane flow disc impellers used to ensure adequate mixing in the vertical direction and (c) a heavy duty electric motor $(0.5 \mathrm{hp})$ with a gear head reducer mounted on the tank and connected to a mixing speed controller. The digester was provided with heat exchanger for heating to maintain required temperature of materials. The gas was collected in the bag made of polyethylene ( 250 Micron thickness).

The heating system consists of heating tank $1.0 \mathrm{~m}^{3}$ capacity that used for heating water. Dimensions of heating tank are $1.0 \mathrm{~m}$ diameter and $1.3 \mathrm{~m}$ high. It is made of polyethylene and covered by glass rock sheet. Electric heater $(2 \mathrm{~kW})$ was used to heating water. The hot water was circulated by a pump (Model First QB60 - Flow Rate $30 \mathrm{~L} \mathrm{~min}^{-1}$ - Head $25 \mathrm{~m}$ - Power $0.5 \mathrm{hp}$, China) from the heating tank to the heat exchanger. The hot water was pumped to the heat 
exchanger by pump through iron pipes of 1.0 inch in diameter. Figure (2) shows the heating system.

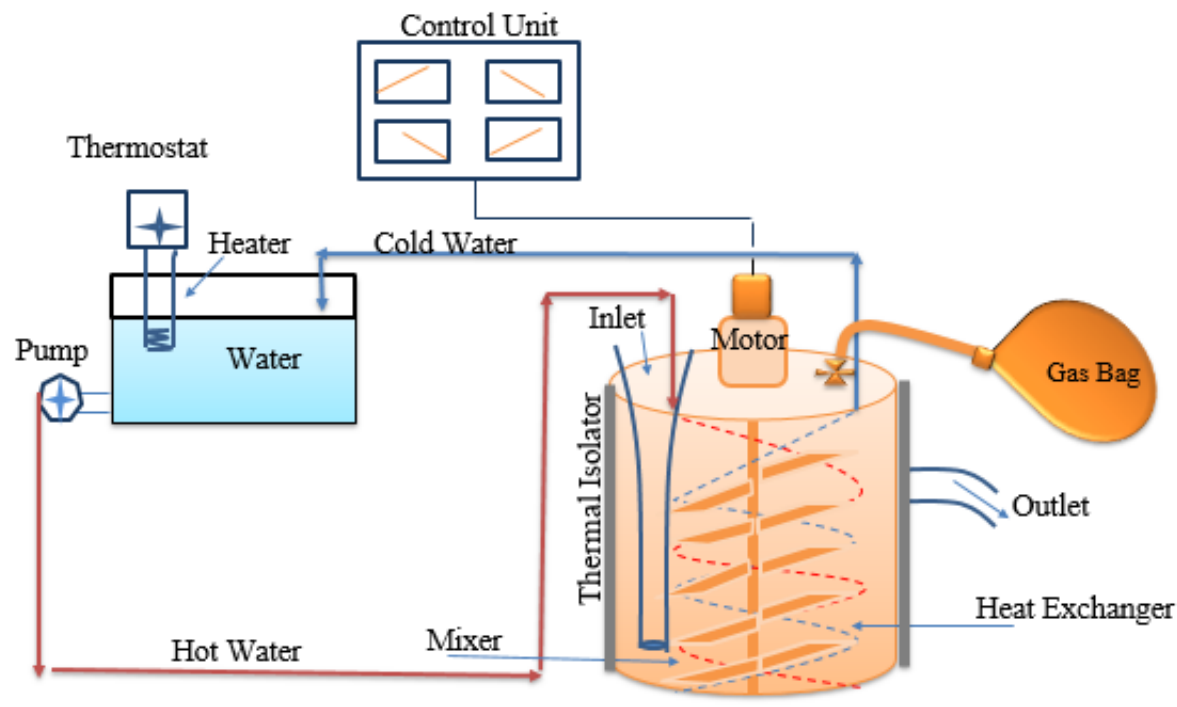

Figure (2): The heating system.

\subsection{Raw materials:}

The agricultural wastes used for biogas production are cattle manure, poultry litter and rice straw. The agricultural wastes used was produced from farmers at Experimental Research Station at the Faculty of agriculture, Moshtohor, Benha University. The properties that used in the manufacturing the biogas are listed in table (1).

Table (1): Properties of the raw materials used in biogas making.

\begin{tabular}{llll}
\hline Properties & Cattle Manure & Poultry Litter & Rice Straw \\
\hline PH & 7.03 & 8.2 & 6.93 \\
Moisture content (\%) & 83 & 67.5 & 10.9 \\
Total solid (\%) & 17 & 32.5 & 89.1 \\
Volatile solid (\%) & 80 & 75 & 78 \\
C/N Ratio & 24.8 & 7.7 & 74.7 \\
Total Nitrogen (\%) & 0.29 & 1.84 & 0.54 \\
Total Carbon (\%) & 7.2 & 14.14 & 40.31 \\
\hline
\end{tabular}

\section{Methods:}

\subsection{Treatments:}

Seven different types of mixing were obtained by mixing dairy manure with poultry litter and rice straw at different ratios to form:

1- $C_{1}$ : Dairy manure (100:0)

2- $\mathrm{C}_{2}$ : Poultry litter (100:0)

3- $\mathrm{C}_{3}$ : Dairy manure, poultry litter and rice straw $(25: 25: 50)$

4- $\mathrm{C}_{4}$ : Dairy manure and rice straw $(20: 80)$

5- $\mathrm{C}_{5}$ : Dairy manure and rice straw $(80: 20)$

6- $\mathrm{C}_{6}$ : Dairy manure, poultry litter and rice straw (40:40:20)

7- $\mathrm{C}_{7}$ : Poultry litter and rice straw (50:50)

\subsection{Measurements:}

Total solids content (TS) were determined according to the following equation:

$$
\mathrm{TS}=\frac{M D S}{\mathrm{MFS}} \times 100
$$

Where:

TS is the total solids, \%

MDS is the mass of dry sample, $g$

MFS is the mass of fresh sample, $g$

The volatile solids content (VS) were determined according to the following equation:

$$
\mathrm{V} S=M S D-\frac{\mathrm{MASH}}{\mathrm{MSD}} \times 100
$$

Where:

VS is the volatile solids, \%

MASH is the mass after ignition, $g$ 
The biogas yield was measured daily by using the following equation:

$$
\mathrm{V}=\left(\mathrm{W}_{1}-\mathrm{W}_{2}\right) \times \rho
$$

Where:

$\mathrm{V}$ is the biogas, $\mathrm{m}^{3}$

$\mathrm{W}_{1}$ is the bag weight with gas, $\mathrm{g}$

$\mathrm{W}_{2}$ is the bag weight empty, $\mathrm{g}$

$\rho$ is the biogas density, $0.717 \mathrm{~kg} \mathrm{~m}^{-3}$

The composition of biogas was measured by gas chromatography analysis.

The daily gas production was measured by collecting the produced gas in bag used to collect the gas. This was connected to the fitting to regulate the flow of gas in / out of the bag and weight it.

\section{Results and Discussion:}

\section{Total solids of slurry (TS):}

Figure (3) shows the total solids of slurry (TS) of different types of mixing (Dairy manure (100:0), Poultry litter (100:0), Dairy manure, poultry litter and rice straw (25:25:50), Dairy manure and rice straw (20:80), Dairy manure and rice straw (80:20), Dairy manure, poultry litter and rice straw (40:40:20) and Poultry litter (3)d rice straw (50:50)) during the retention period. The results indicate that the TS of slurry decreases with increasing retention time. It could be seen the TS of slurry decreased from 8.50 to $0.10,8.12$ to $0.02,15.90$ to $0.33,17.76$ to $0.10,16.13$ to $0.20,13.50$ to 0.32 and 12.66 to $0.18 \%$, when the retention time increased from 1 to 45,1 to 45,1 to 55 , 1 to 65,1 to 55,1 to 50 and 1 to 65 day, respectively, for Dairy manure (100:0), Poultry litter (100:0), Dairy manure, poultry litter and rice straw (25:25:50), Dairy manure and rice straw (20:80), Dairy manure and rice straw (80:20), Dairy manure, poultry litter and rice straw (40:40:20) and Poultry litter and rice straw (50:50), respectively.

The results indicate that the highest rate of the decrease total solids of slurry $(99.75 \%)$ was happened with the Poultry litter (100:0). Meanwhile, the lowest rate of the decrease total solids of slurry $(97.76 \%)$ was found with Dairy manure, poultry litter and rice straw (40:40:20).

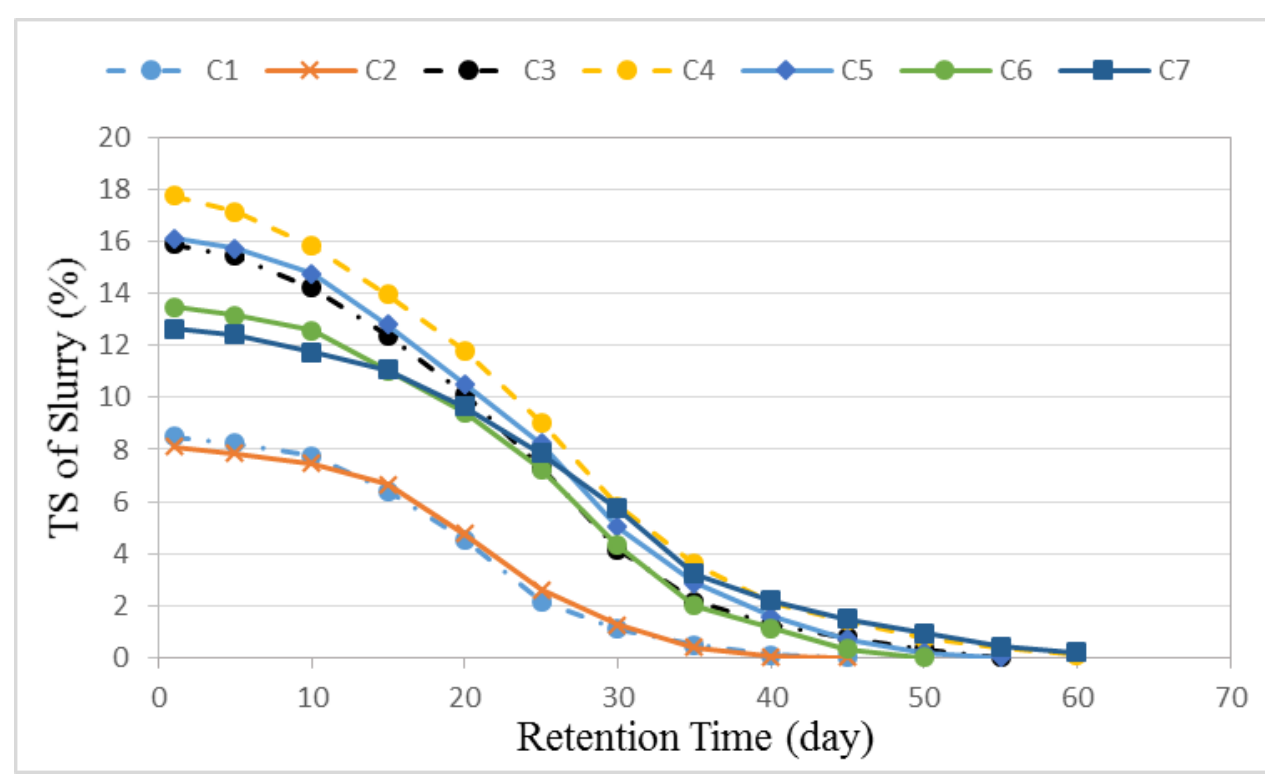

Figure (3): The total solids of slurry (TS) of different types of mixing during the retention period.

\section{Volatile solids of slurry (VS):}

Figure (4) shows the volatile solids of slurry (VS) of different types of mixing (Dairy manure (100:0), Poultry litter (100:0), Dairy manure, poultry litter and rice straw (25:25:50), Dairy manure and rice straw (20:80), Dairy manure and rice straw (80:20), Dairy manure, poultry litter and rice straw (40:40:20) and Poultry litter and rice straw (50:50)) during the retention period. The results indicate that the VS of slurry decreases with increasing retention time. It could be seen the VS of slurry decreased from 6.80 to $0.08,6.09$ to $0.01,12.36$ to $0.25,13.92$ to $0.08,12.84$ to $0.16,10.48$ to 0.25 and 9.69 to $0.13 \%$, when the retention time increased from 1 to 45,1 to 45,1 to 55 ,
1 to 65,1 to 55,1 to 50 and 1 to 65 day, respectively, for Dairy manure (100:0), Poultry litter (100:0), Dairy manure, poultry litter and rice straw (25:25:50), Dairy manure and rice straw (20:80), Dairy manure and rice straw (80:20), Dairy manure, poultry litter and rice straw (40:40:20) and Poultry litter and rice straw (50:50), respectively.

The results indicate that the highest rate of the decrease volatile solids of slurry $(99.84 \%)$ was happened with the Poultry litter (100:0). Meanwhile, the lowest rate of the decrease total solids of slurry $(97.61 \%)$ was found with Dairy manure, poultry litter and rice straw (40:40:20). 


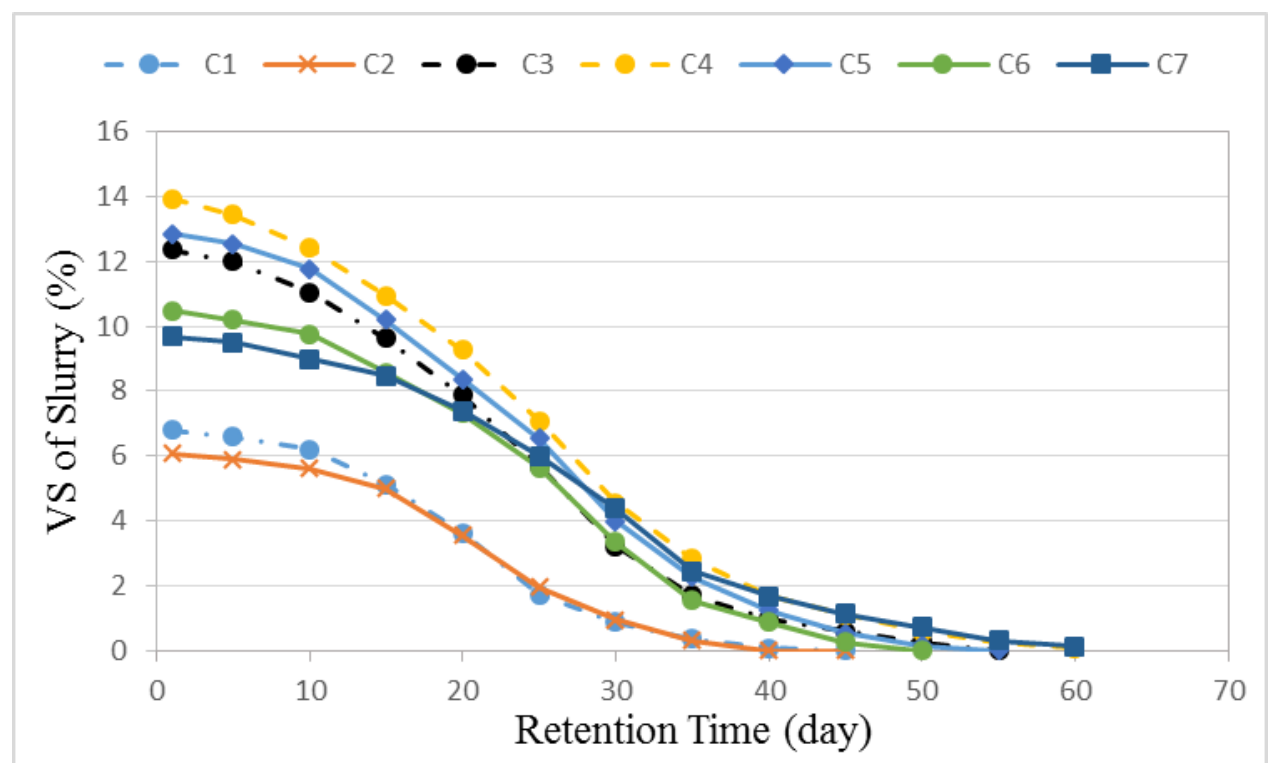

Figure (4): The volatile solids of slurry (VS) of different types of mixing during the retention period.

\section{Biogas yield:}

Figure (5) shows the accumulated biogas yield of different types of mixing (Dairy manure (100:0), Poultry litter (100:0), Dairy manure, poultry litter and rice straw (25:25:50), Dairy manure and rice straw (20:80), Dairy manure and rice straw (80:20), Dairy manure, poultry litter and rice straw (40:40:20) and Poultry litter and rice straw (50:50)) during the retention period. The results indicate that the accumulated biogas yield increases with increasing retention time. It could be seen the accumulated biogas yield increased from 7.35 to $250,8.46$ to 259.2 , 6.52 to $229.96,8.24$ to $239.98,5.65$ to $229.97,6.48$ to 249.98 and 4.64 to $260.93 \mathrm{~m}^{3}$ per ton TS, when the retention time increased from 5 to 45,5 to 45,5 to 55 , 5 to 65,5 to 55,5 to 50 and 5 to 65 day, respectively, for Dairy manure (100:0), Poultry litter (100:0), Dairy manure, poultry litter and rice straw (25:25:50), Dairy manure and rice straw (20:80), Dairy manure and rice straw (80:20), Dairy manure, poultry litter and rice straw (40:40:20) and Poultry litter and rice straw (50:50), respectively. These results agreed with those obtained by Qiao et al. (2011).

The results indicate that the highest value of accumulated biogas yield $\left(260.93 \mathrm{~m}^{3}\right.$ per ton TS) was found with the Poultry litter and rice straw (50:50). Meanwhile, the lowest value of accumulated biogas yield $\left(229.96 \mathrm{~m}^{3}\right.$ per ton TS) was found with Dairy manure, poultry litter and rice straw $(25: 25: 50)$.

The results indicate that the accumulated biogas yield increases with increasing total solids of slurry, it could be seen that the biogas yield increased from 16.24 to $35.52 \mathrm{~m}^{3}$ per ton TS when the total solids increased from 8.12 to $17.76 \%$.

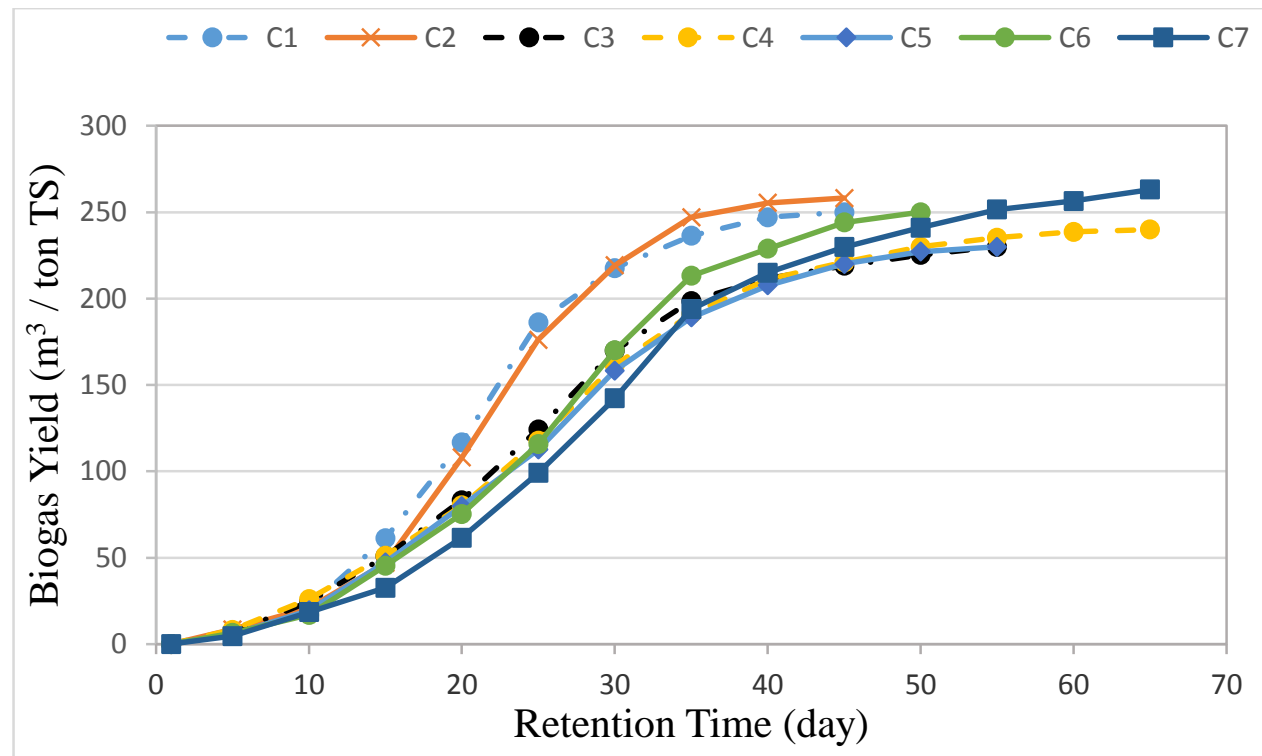

Figure (5): The accumulated biogas yield of different types of mixing during the retention period. 


\section{Methane yield:}

Figure (6) shows the accumulated methane yield of different types of mixing (Dairy manure (100:0), Poultry litter (100:0), Dairy manure, poultry litter and rice straw (25:25:50), Dairy manure and rice straw (20:80), Dairy manure and rice straw (80:20), Dairy manure, poultry litter and rice straw (40:40:20) and Poultry litter and rice straw (50:50)) during the retention period. The results indicate that the accumulated methane yield increases with increasing retention time. It could be seen the accumulated methane yield increased from 4.60 to $156.30,5.18$ to $159.12,4.85$ to $171.11,5.55$ to $161.85,4.11$ to 167.03 , 4.12 to 159.11 and 3.50 to $196.10 \mathrm{~m}^{3}$ per ton TS, when the retention time increased from 5 to 45,5 to 45,5 to 55,5 to 65,5 to 55,5 to 50 and 5 to 65 day, respectively, for Dairy manure (100:0), Poultry litter (100:0), Dairy manure, poultry litter and rice straw (25:25:50), Dairy manure and rice straw (20:80), Dairy manure and rice straw (80:20), Dairy manure, poultry litter and rice straw (40:40:20) and Poultry litter and rice straw (50:50), respectively.

The results indicate that the highest value of accumulated methane yield $\left(196.10 \mathrm{~m}^{3}\right.$ per ton TS) was found with the Poultry litter and rice straw (50:50). Meanwhile, the lowest value of accumulated methane yield $\left(156.30 \mathrm{~m}^{3}\right.$ per ton TS) was found with Dairy manure (100:0).

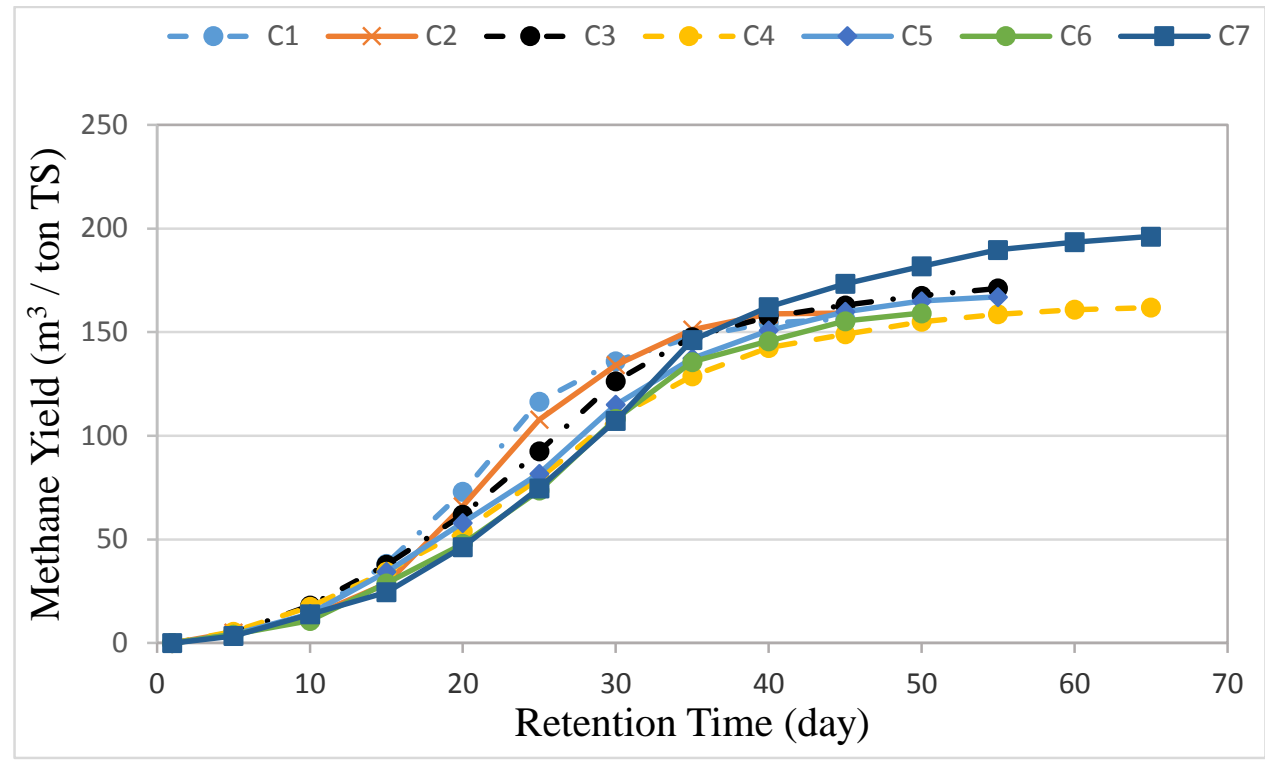

Figure (6): The accumulated methane yield of different types of mixing during the retention period.

\section{5. $\mathrm{CO}_{2}$ yield:}

Figure (7) shows the accumulated $\mathrm{CO}_{2}$ yield of different types of mixing (Dairy manure (100:0), Poultry litter (100:0), Dairy manure, poultry litter and rice straw (25:25:50), Dairy manure and rice straw (20:80), Dairy manure and rice straw (80:20), Dairy manure, poultry litter and rice straw (40:40:20) and Poultry litter and rice straw (50:50)) during the retention period. The results indicate that the accumulated $\mathrm{CO}_{2}$ yield increases with increasing retention time. It could be seen the accumulated $\mathrm{CO}_{2}$ yield increased from 2.55 to $86.85,3.16$ to $97.24,1.61$ to $56.82,2.55$ to $74.42,1.49$ to $60.41,2.26$ to 87.02 and 1.04 to $58.10 \mathrm{~m}^{3}$ per ton TS, when the retention time increased from 5 to 45,5 to 45,5 to 55,5 to 65 ,
5 to 55,5 to 50 and 5 to 65 day, respectively, for Dairy manure (100:0), Poultry litter (100:0), Dairy manure, poultry litter and rice straw (25:25:50), Dairy manure and rice straw (20:80), Dairy manure and rice straw (80:20), Dairy manure, poultry litter and rice straw (40:40:20) and Poultry litter and rice straw (50:50), respectively.

The results indicate that the highest value of accumulated $\mathrm{CO}_{2}$ yield $\left(97.24 \mathrm{~m}^{3}\right.$ per ton TS) was found with the Poultry litter (100:0). Meanwhile, the lowest value of accumulated $\mathrm{CO}_{2}$ yield $\left(56.82 \mathrm{~m}^{3}\right.$ per ton TS) was found with Dairy manure, poultry litter and rice straw (25:25:50). 


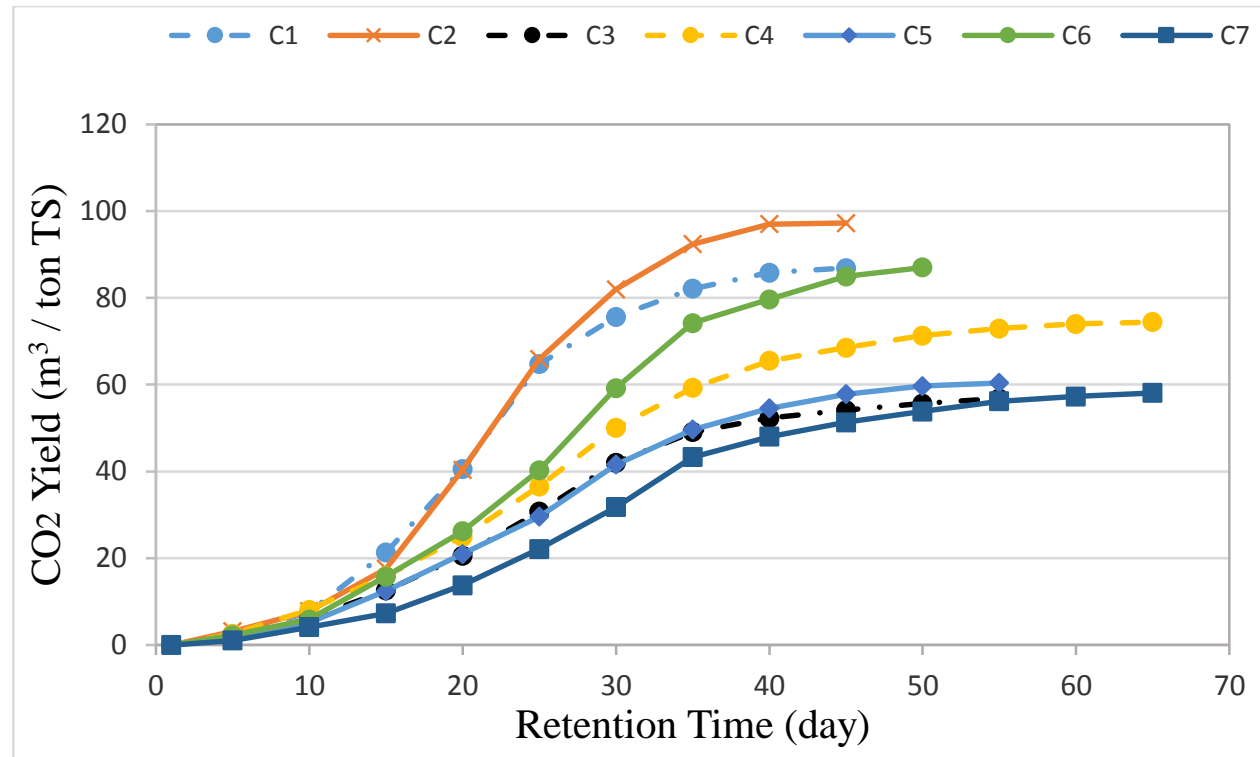

Figure (7): The accumulated $\mathrm{CO}_{2}$ yield of different types of mixing during the retention period.

\section{6. $\mathrm{H}_{2} \mathrm{~S}$ yield:}

Figure (8) shows the accumulated $\mathrm{H}_{2} \mathrm{~S}$ yield of different types of mixing (Dairy manure (100:0), Poultry litter (100:0), Dairy manure, poultry litter and rice straw (25:25:50), Dairy manure and rice straw (20:80), Dairy manure and rice straw (80:20), Dairy manure, poultry litter and rice straw (40:40:20) and Poultry litter and rice straw (50:50)) during the retention period. The results indicate that the accumulated $\mathrm{H}_{2} \mathrm{~S}$ yield increases with increasing retention time. It could be seen the accumulated $\mathrm{H}_{2} \mathrm{~S}$ yield increased from 0.14 to $4.75,0.07$ to $2.08,0.05$ to $1.58,0.07$ to $2.10,0.03$ to $1.38,0.06$ to 2.25 and 0.07 to $4.16 \mathrm{~m}^{3}$ per ton TS, when the retention time increased from 5 to 45,5 to 45,5 to 55,5 to 65,5 to 55,5 to 50 and 5 to 65 day, respectively, for Dairy manure (100:0), Poultry litter (100:0), Dairy manure, poultry litter and rice straw $(25: 25: 50)$, Dairy manure and rice straw (20:80), Dairy manure and rice straw (80:20), Dairy manure, poultry litter and rice straw (40:40:20) and Poultry litter and rice straw (50:50), respectively.

The results indicate that the highest value of accumulated $\mathrm{H}_{2} \mathrm{~S}$ yield $\left(4.75 \mathrm{~m}^{3}\right.$ per ton TS) was found with the Dairy manure (100:0). Meanwhile, the lowest value of accumulated $\mathrm{H}_{2} \mathrm{~S}$ yield $\left(1.38 \mathrm{~m}^{3}\right.$ per ton TS) was found with Dairy manure and rice straw (80:20).

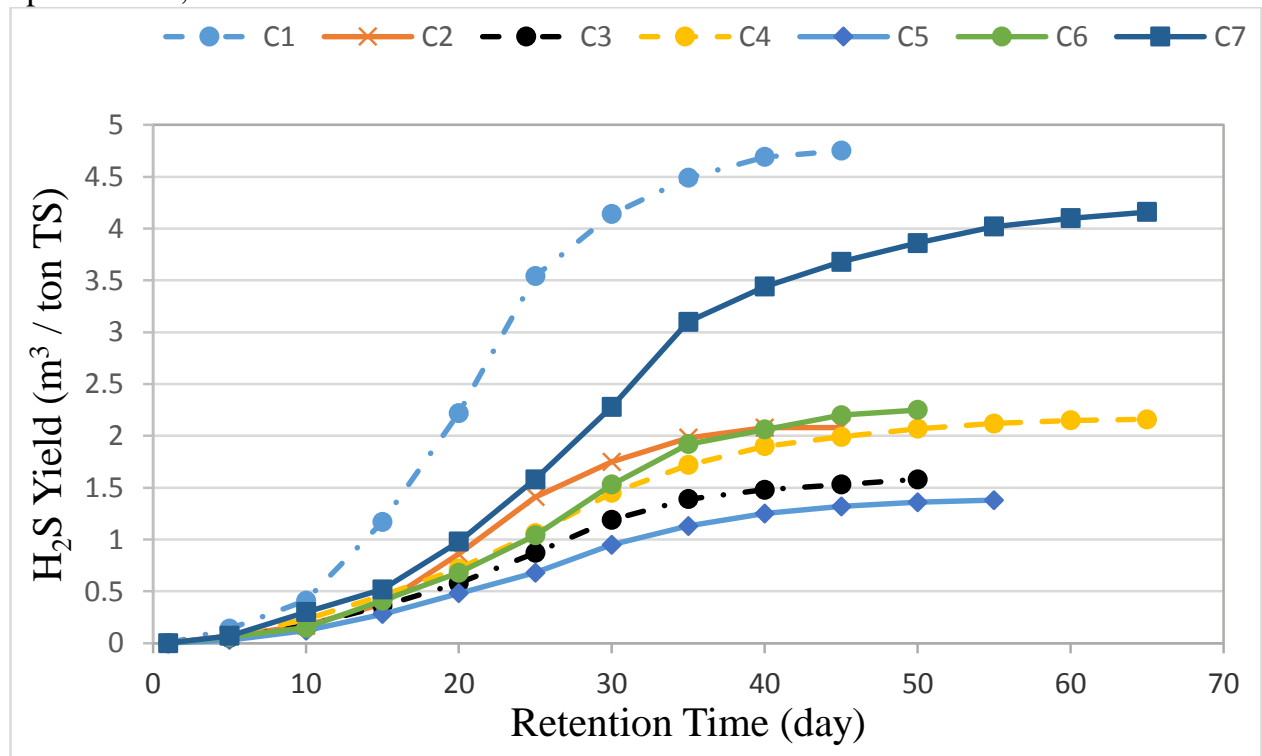

Figure (8): The accumulated $\mathrm{H}_{2} \mathrm{~S}$ yield of different types of mixing during the retention period.

\section{Conclusion}

The experiment was carried out to study the biogas production from different agricultural residues to overcome the energy scarcity and environmental pollution. The treatments under study are: Dairy manure (100:0), Poultry litter (100:0), Dairy manure, poultry litter and rice straw $(25: 25: 50)$, Dairy manure 
and rice straw (20:80), Dairy manure and rice straw (80:20), Dairy manure, poultry litter and rice straw (40:40:20) and Poultry litter and rice straw (50:50). The obtained results can be summarized as follows:

The total solids (TS) and volatile solids (VS) of slurry decrease with increasing retention time for all treatments. The highest value of accumulated biogas yield $\left(260.93 \mathrm{~m}^{3}\right.$ per ton TS) was found with the Poultry litter and rice straw (50:50). Meanwhile, the lowest value of accumulated biogas yield $\left(229.96 \mathrm{~m}^{3}\right.$ per ton TS) was found with Dairy manure, poultry litter and rice straw (25:25:50). The highest value of accumulated methane yield $\left(196.10 \mathrm{~m}^{3}\right.$ per ton TS) was found with the Poultry litter and rice straw (50:50). Meanwhile, the lowest value of accumulated methane yield (156.30 $\mathrm{m}^{3}$ per ton TS) was found with Dairy manure (100:0). $\mathrm{CO}_{2}$ and $\mathrm{H}_{2} \mathrm{~S}$ increase with increasing retention time for all treatments.

\section{References}

Angelidaki, I., Ellegaard, L., Ahring, B.K. (2003). Application of the anaerobic digestion process. Adv. Biochem. Eng./Biotechnol. Biomethanat. II 82, 1-33.

Appels, L., Baeyens J., Degrève J., Dewil R. (2008). Principles and potential of the anaerobic digestion of waste-activated sludge. Progress in Energy and Combustion Science, 34: 755 - 781.

Callaghana, F.J., Wasea D.A.J., Thayanithya K. (2002). Continuous co-digestion of cattle slurry with fruit and vegetable wastes and chicken manure. Biomass and Bioenergy, 27: 71 - 77.

Fernandes, T.V., Klaasse Bos G.J., Zeeman G., Sanders J.P.M., van Lier J.B. (2009). Effects of thermo-chemical pre-treatment on anaerobic biodegradability and hydrolysis of lignocellulosic biomass. Bioresour. Technol. 100 (9), 2575-2579.

Hausknost, D., Schriefl, E., Lauk, C., Kalt, G.A. (2017). Transition to Which Bioeconomy an
Exploration of Diverging Techno-Political Choices. Sustainability, 9, 669.

Hayashi, K., Hondo H., Moriizumi Y. (2016). Preference Construction Processes for Renewable Energies Assessing the Influence of Sustainability Information and Decision Support Methods. Sustainability, 8, 1114.

Kaparaju, P., Rintala J. (2005). Anaerobic codigestion of potato tuber and its industrial byproducts with pig manure. Resources, Conservation and Recycling, 43: 175 - 188.

Lakatos, E.S., Dan V., Cioca L.I., Bacali, L., Ciobanu A.M. (2016). How Supportive Are Romanian Consumers of the Circular Economy Concept A Survey. Sustainability, 8, 789.

Li, X.J., Li L.Q., Zheng M.X., Fu G.Z., Lar J.S. (2009). Anaerobic co-digestion of cattle manure with corn stover pretreated by sodium hydroxide for efficient biogas production. Energy Fuels, 23, 4635 - 4639.

Meyer, R. (2017). Bioeconomy Strategies Contexts, Visions, Guiding Implementation Principles and Resulting Debates. Sustainability, 9, 1031.

Qiao, W., Yan X., Ye J., Sun Y., Wang W., Zhang Z. (2011). Evaluation of biogas production from different biomass wastes with/without hydrothermal pretreatment. Renewable Energy, 36, 3313 - 3318

Van der Berg, L., Kennedy K.J. (1983). Comparison of advanced anaerobic reactors. In: Proceedings of III International Conference on Anaerobic digestion, August 1983, Boston, NRCC no.22613.

Wan, C.X., Zhou Q.C., F, G.M., L, Y.B. (2011). Semi-continuous anaerobic codigestion of thickened waste activated sludge and fat, oil and grease. Waste Manage., 31, 1752-1758.

Zhang, Y., Banks C.J., Heaven S. (2012). Codigestion of source segregated domestic food waste to improve process stability. Bioresour. Technol., 114, 168-178. 


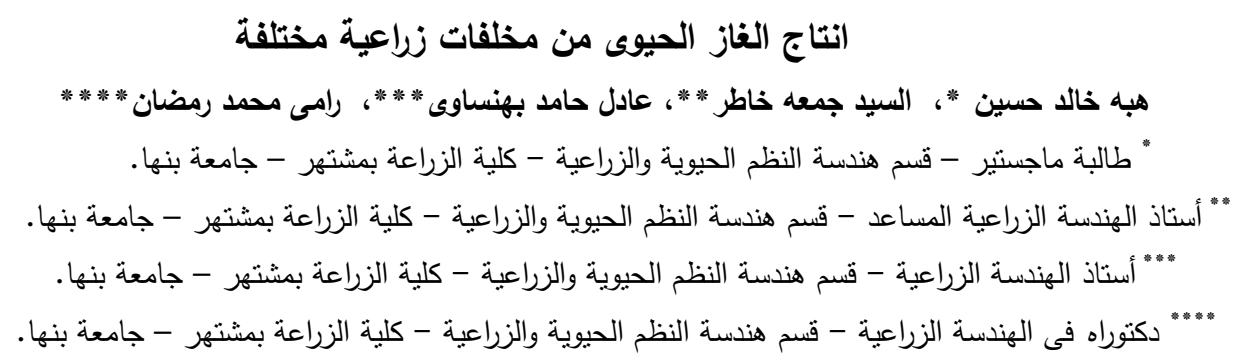

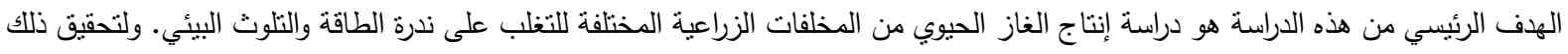

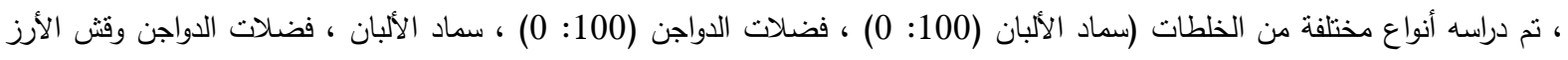

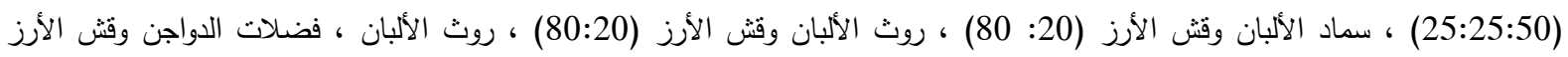

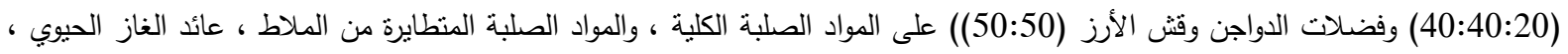

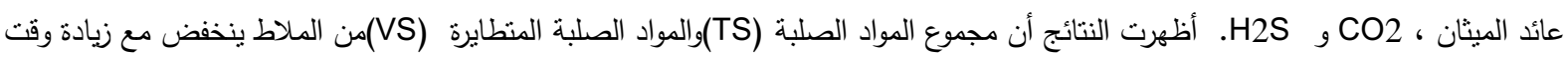

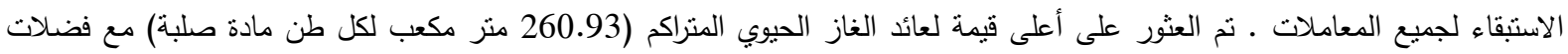

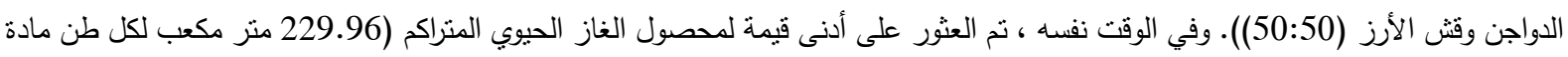

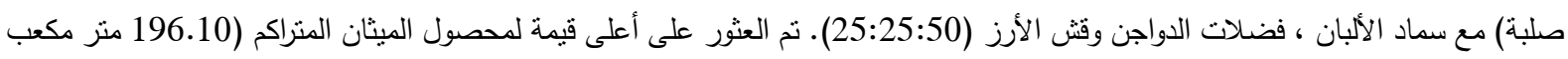

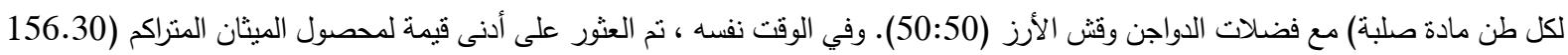

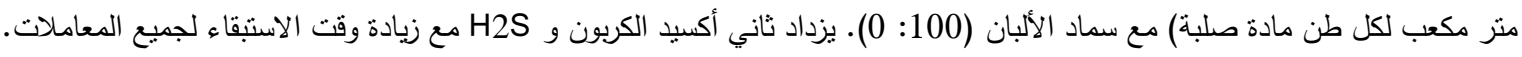

